\title{
EGFR NP_005219.2:p.L747_E749del
}

National Cancer Institute

\section{Source}

National Cancer Institute. EGFR NP 005219.2:p.L747 E749del. NCI Thesaurus. Code C98554.

A deletion of three amino acids from the epidermal growth factor receptor protein from the leucine at position 747 through the glutamic acid at position 749. 